\title{
The Impact Of Business Support Services To SMMEs In South Africa
}

Motshedisi S. Mathibe, University of the Free State, South Africa Johan H. van Zyl, University of the Free State, South Africa

\begin{abstract}
Small Medium and Micro Enterprises in South Africa were operating in the era of the apartheid regime but were not given enough support and were not a priority in the government of those days. Before democratic transition, the South African government was mainly giving attention to large businesses as well as state-owned enterprises. It was only in the late 1970s and the early 1980s that the South African government realised the importance of the small enterprise sector and its contribution to the country's economy. The democratic regime of the early 1990 s gave SMMEs an opportunity to participate in the South African economy. A White Paper of 1995 introduced the strategy to promote and develop SMMEs in South Africa and to design an SMME policy framework that will focus its attention on supporting and developing SMMEs. The aim was to enable SMMEs to grow as a way of creating a balance in the economy (away from state-owned and large enterprises) As a result, different support mechanisms have been implemented to support and develop SMMEs in the country since the democratic government took over in 1994.
\end{abstract}

This paper evaluates the business support programmes that have been implemented in South Africa since 1994, specifically in the Free State Province for the development and support of SMMEs. In this respect, the paper compares and evaluates the ability of the business support programmes that have been put in place to develop and support SMMEs in order to grow and become sustainable. This is done by means of a brief overview of the international business support services and an assessment of the South African SMME policy environment. The study also conducted five structured interviews with the management representative of the five different business support programmes in the Free State Province.

Some of the key findings indicate that not many SMMEs are aware of business support programmes in the Free State and are even less informed as to where to access finances. At the same time, it was found that staff responsible for business support programmes appears to be incompetent, and therefore, deliver poor quality services. From this study it can be concluded that of all the programmes the government-driven initiatives to develop and support SMMEs struggle the most to become operational. The business support programmes focused on markets to some degree, but seldom made it an inherent requirement. This paper recommends that there should be monitoring and evaluation systems available to document the quality of the service delivery to SMMEs in the Province, and to train the staff of the business support programmes to deliver high-quality services to entrepreneurs. The study compared five business support programmes in the Free State with regards to developing and supporting SMMEs in the province. As a result, the value of the findings might well be considered in terms of future provincial planning documents and policy.

Keywords: Business Support Programmes; SMMEs; Supply Driven Approach; Demand Driven Approach

\section{INTRODUCTION}

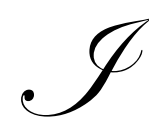

$\mathrm{t}$ should be noted that other countries use the concept of Small and Medium Enterprise (SMEs), while in South Africa; the concept used changes to Small, Micro and Medium Enterprises (SMMEs). The promotion and support of the small, medium and micro enterprises (SMMEs) sector has become a major policy matter in the structure of business support agencies in post-apartheid South Africa (Kesper, 2001; Adams, 2003; Rogerson, 2004). SMMEs in South Africa were operating in the era of the apartheid regime but were not given enough support and were not a priority in the apartheid government. Before the democratic transition, the 
South African government was mainly paying attention to large businesses as well as state-owned enterprises. It was only in the late 1970s and the early 1980s that the South African government realised the importance of the small enterprise sector and its contribution to the country's economy. The democratic regime of the early 1990s gave SMMEs an opportunity to participate in the South African economy. A White Paper of 1995 introduced the strategy to promote and develop SMMEs in South Africa and to design an SMME policy framework that will focus its attention on supporting and developing SMMEs. The aim was to enable SMMEs to grow as a way of creating a balance in the economy (away from state-owned and large enterprises). As a result, different support mechanisms have been implemented to support and develop SMMEs in the country since the democratic government took over in 1994. With the democratisation of South Africa, huge emphasis was placed on rectifying inequalities in respect of business support programmes to small enterprises in South Africa (DTI, 2002; 2005; Rogerson, 2005; Seda Annual Report, 2007).

This paper compares and evaluates the impact of business support programmes on SMMEs in the Free State. In this respect the paper compares following five business support programmes, namely, the Small Enterprise Development Agency (Seda), Umsobomvu Youth Fund (UYF), Premier's Project, the Basic Entrepreneurial Skill Development (BESD) Approach, and the Free State Development Corporation (FDC). The paper specifically examines the ability of these five business support programmes to grow small enterprises. The discussion commences with an overview of the paradigm shift in business support programmes at international level. This is followed by a brief reflection of policy directions taken in South Africa. Finally, a comparison of business support programmes in the Free State and the lessons from the comparison are considered and a number of concluding comments shared.

\section{METHODOLOGY}

Three main methodological procedures were followed in order to complete this study, namely a literature review, survey method and sampling method.

Firstly, an extensive international literature review was conducted on the paradigm shift of business support services. The focus was on the paradigm shift of business support in the past three decades. Moreover, the literature review provided relevant information regarding the background of business support services internationally as well as locally. Secondly, a qualitative survey in which five individual interviews were conducted with the management representatives of the five participating business support programmes in the Free State. In this regard, semistructured interviews were conducted to compare five business support programmes in terms of the trends identified in the international literature (Mcmillan \& Schumacher, 2001). This helped to further clarify issues that could not be covered via the structured questionnaire method.

\section{PARADIGM SHIFT OF BUSINESS SUPPORT: THE GLOBAL CONTEXT}

Internationally, business support services experienced a major change with regard to developing and supporting SMEs in the past three decades. Donor foundations and multinational companies focused their expectations on SMEs as a means to build the global economies and to provide employment to the poor. Yet, the approach to business support services was not fully explored (Tanburn 2006).

Although the importance of SME development has grown over the past three decades, there has always been criticism with regard to development and support of SMEs globally. Schmitz (1998) identified six main points of criticism in respect of the traditional approach to business support. Firstly, the high level of subsidies requiring continuous public support was highlighted as one of the main problems. The insufficient outreach of the government to SMEs was identified as the second problem. Deficit spending as well as the improper handling of substantial inflows of foreign aid was identified as the third major problem leading to very few entrepreneurs being reached. Fourthly, the general support of interventions together with the personnel of these interventions was not designed to encourage partnership with the business sector or even to pursue customer satisfaction. Next, poor quality of services became common in the industry and low quality products were delivered at a low cost, or free of charge. Lastly, an increasing number of private competitors lead to highly subsidised rates of service delivery, and this resulted in market distortions and also hampered the emergence of commercially viable service providers. Hence, 
non-financial support was too supply-oriented and rarely sustainable. given the above scenario, there was an urgent demand for a shift away from the traditional approach of business support by the mid-1990s as this approach was not addressing the needs of SMEs (see for example Goldman 1996; Mclntyre and Dallago, 2003; Gorman and McCarthy, 2006; Meyer-stamer, 2006). The shift consisted of two interrelated aspects namely: the concept of Making-markets-work-for-the-poor and the changes in business support services

\section{MAKING MARKETS WORK FOR THE POOR (MMWP)}

In line with the emphasis on demand-driven business support programmes, the MMWP developed. The concept of 'MMWP' has only been popularised during the last decade or two (Harper and Tanburn, 2005). This concept is still new and there is not enough literature concerning it. In fact, Schrimer (2005) argues that more research needs to be done regarding this concept. As in many other cases, poor people were left behind in terms of accessing markets (Kashyap, 1991). In practice this could mean playing a specific regulatory role, for example through ensuring trade agreements with SMEs (Mfaume and Leonard, 2004). However, in order to understand why markets work, or why they do more frequently in other countries but not in poor countries, it is essential to look not only at the markets themselves, but also at SMEs. One should ask whether these SMEs have the required skills and experience to run their businesses. One should also consider the involvement and the role of the government in ensuring that these SMEs obtain skills - in order to access markets (Sida, 2003; DFID, 2000; UNDP, 2004; World Bank, 2005).

\section{CHANGES IN BUSINESS SUPPORT}

This section aims to highlight key changes in business support that contributed to the paradigm shift. In this respect, Harper and Tanburn (2005) identify six changes in business support that have taken place over the past years in the international arena. These relate to sustainability of provision, cost of services, client focus, poverty, gender impact, services provided, and the rise of the concept of 'making markets work for the poor'.

Harper (2005) identifies six main changes in the approach to business support. First, permanent government or donor funding was replaced by a mere start-up funding approach in order to provide sustainable business support services. Second, a larger range of market-driven and market-priced services that were delivered at a quality/price mix determined by end-users replaced the high costs of a limited range of services that used to be subsidised. Third, historically, literature shows that government and donors could not reach all small businesses but a limited number, and therefore a targeted client approach was introduced in order for the government and donors to reach them effectively (Orford, 2005:21). This paradigm shift was intended to place an emphasis on service providers in the private-sector (see also Committee of Donors, 2001). Fourth, the emphasis on the impact of poverty changed from one of short-term benefits to one of long-term benefits to providers and clients, indirectly benefiting the poor through job creation. Next, the mainly male clientele was replaced by small-enterprise owners which included females. Finally, there was a significant shift towards being demand-driven in respect of the needs of enterprises. This meant both that the range of services was expanded and that they were mostly delivered on a costrecovery basis.

\section{SOUTH AFRICAN SMME POLICY AND PRACTICE}

This section sketches and evaluates the South African SMME policy framework and the policy development towards promoting the small business economy. Although there are several policies on SMME development, the emphasis in this paper is on the 1995 framework strategy for SMME support and development in South Africa and the 2005 Integrated Small Business Strategy in South Africa. The specific attention is given to key policy objectives towards SMME development, the support structure and current business support programmes that the democratic government have been implemented to promote SMMEs. It should be noted that the international literature on small business support refers to Small and Medium Enterprises (SMEs) (Goss, 1991). In the South African context, however, there is a reference to Small, Medium and Micro Enterprises (SMMEs), which include a large survivalist sector (see Rogerson, 1998).

After government realised the importance of the SMMEs in the country's economy, they implemented business support mechanisms for the support and development of SMMEs (Adams, 2003; Rogerson, 2004). The first 
business support programme to be established is the Small Business Development Corporation (SBDC) in the early 1980s. The initiative was established mainly as a financial provider with limited non-financial business services (DTI, 2000; von Broembsen, 2003). However, the establishment of the SBDC did very little to refocus business development away from a bias towards white-owned enterprise. It was only in the late 1980s and early 1990s that some attention was devoted to previously disadvantaged enterprises. The political shifts of the early 1990s contributed to an increasing research interest in small business development and its contribution to the country's economy. A 1995 framework strategy for small business support and development in South Africa introduced a new strategy to promote, develop and support small businesses. The aim of the strategy was to enable the growth and sustainability of small businesses as a way of creating a balance in the economy (away from state-owned and large enterprises) (White paper, 1995; Bloch and Kesper, 2000; Berry, von Blottnitz, Cassin, Kesper, Rajaratman and van Seventer, 2002).

However, the 1995 strategy for achieving growth seldom addressed the needs of the SMMEs, and, as a result, the gap between economic growth and employment growth was widening due to the fact that poor people lack the skills to integrate into the current processes of economic growth (National Small Business Enabling Act, 1996; Phillips, 2002; Berry et al., 2002; South African Human Development Report, 2003). In response to this need, the government implemented business support programmes (such as Khula and Ntsika) to assist small business to acquire the necessary skills (Berry, et. al.,2002; Wren and Storey, 2002). These two business support agencies have been the key business support programmes used by the post-apartheid government to support and develop SMMEs in South Africa (White Paper, 2005). The overall evaluation of business support programmes during this phase is that they remained supply driven, with very little focus on markets while government structures were not always geared to address the needs. (also see McQuaid, 2002; Thurlow and Wobst, 2004; Rogerson, 2007).

By the mid-2000s, there was increasing pressure to evaluate and rethink the South African small business policy. This culminated in the Integrated Small Business Strategy of 2005. The vision reflected in this strategy is one of making South Africa "an entrepreneurial nation" providing reward to individuals seeking business opportunities; establishing a vibrant and competitive small enterprise sector, and providing business support programmes to previously disadvantaged individuals (DTI 2006). The strategy is based on three pillars of support that are aimed at empowering entrepreneurs in South Africa. These include promoting entrepreneurship, creating enabling environments and enhancing the competitiveness and capabilities of existing enterprises (White Paper, 2005; Mkhize, 2006). Although there are similarities with the 1995 White Paper, the new strategy re-emphasises a number of issues, for example, the seven SMME developmental support objectives that need strong commitment, leadership and regular monitoring and evaluation by the national, provincial and local governments (White Paper, 2005). These objectives include addressing business growth and transformation within the second economy; initiating a broad entrepreneurship drive and expanding education and training for small businesses; substantially strengthening support for SMME's access to finance; the further expansion of market opportunities for targeted small enterprises; facilitating the systematic expansion of sector support for SMMEs; creating a national information network for SMMEs underpinned by comprehensive research; and co-funding the establishment of minimum business - infrastructure facilities In addition, the main aim of the strategy is to enhance the contribution of small enterprises to the growth of the national economy. This could be done through the creation of sustainable jobs in the SMME sector, and through an enabling environment for SMMEs with a level playing field for both big business and small enterprises that bridges the gap between urban and rural enterprises and is conducive to entrepreneurship (White Paper, 2005; Mkhize, 2006; DTI, 2006; Pretorius and Millard, 2006; Rogerson, 2006; 2007; Agupusi, 2007). This phase also saw the establishment of Seda through which government attempted to consolidate business support under one roof.

\section{EVALUATION OF THE BUSINESS SUPPORT PROGRAMMES: FREE STATE CASE STUDY}

Like many other developing countries, South Africa has been undergoing major paradigm shifts that have led to an increase in the importance of business support services (see Mathibe, 2010). The emphasis in this section shifts towards a conceptual categorisation of five different business support programmes that are functioning in the Free State (although two of these institutions also function nationally, interviews and research were conducted in the Free State only). Essentially, the section answers the questions: to what degree do these business support programmes reflect international trends and to what degree do they reflect policy guidelines as discussed earlier in this paper. Table 1.1 below provides answers to these questions. 
Table 1.1: Comparison of the Free State business support services to SMMEs development

\begin{tabular}{|c|c|c|c|c|c|c|c|}
\hline $\begin{array}{l}\text { Criterial } \\
\text { business } \\
\text { support } \\
\text { programmes }\end{array}$ & $\begin{array}{l}\text { Sustainability } \\
\text { of provision }\end{array}$ & Cost of services & Clients & Poverty impact & Gender impact & $\begin{array}{l}\text { Supply or demand } \\
\text { driven }\end{array}$ & $\begin{array}{l}\text { Making-markets-work- } \\
\text { for-the-poor }\end{array}$ \\
\hline Seda & $\begin{array}{l}\text { Outsourced } \\
\text { services to } \\
\text { reduce long- } \\
\text { term salary } \\
\text { cost }\end{array}$ & $\begin{array}{l}\text { Still large degree } \\
\text { of subsidy for } \\
\text { services, but } \\
\text { entrepreneurs } \\
\text { need to make a } \\
\text { financial } \\
\text { contribution }\end{array}$ & $\begin{array}{l}\text { The inclusion of women } \\
\text { and youth is emphaised } \\
\text { Also emphasis on new } \\
\text { enterprises. }\end{array}$ & $\begin{array}{l}\text { Addressing poverty is } \\
\text { central to the rational } \\
\text { for business support } \\
\text { services }\end{array}$ & $\begin{array}{l}\text { Despite emphasis } \\
\text { to support female } \\
\text { entrepreneurs the } \\
\text { impact is limited }\end{array}$ & $\begin{array}{l}\text { Mainly supply-side } \\
\text { driven }\end{array}$ & $\begin{array}{l}\text { Some focus on markets but } \\
\text { in general not enough } \\
\text { attention }\end{array}$ \\
\hline UYF & $\begin{array}{l}\text { Outsourced } \\
\text { services to } \\
\text { reduce long- } \\
\text { term salary } \\
\text { cost }\end{array}$ & $\begin{array}{l}\text { Still large degree } \\
\text { of subsidy for } \\
\text { services, but } \\
\text { entrepreneurs } \\
\text { need to make a } \\
\text { financial } \\
\text { contribution }\end{array}$ & Mainly youth & $\begin{array}{l}\text { Addressing poverty is } \\
\text { central to the rational } \\
\text { for business support } \\
\text { services }\end{array}$ & $\begin{array}{l}\text { Despite emphasis } \\
\text { to support female } \\
\text { entrepreneurs the } \\
\text { impact is limited }\end{array}$ & $\begin{array}{l}\text { Mainly supply-side } \\
\text { driven }\end{array}$ & $\begin{array}{l}\text { Some focus on markets but } \\
\text { in general not enough } \\
\text { attention }\end{array}$ \\
\hline BESD & $\begin{array}{l}\text { Outsourced } \\
\text { services to } \\
\text { reduce long- } \\
\text { term salary } \\
\text { cost }\end{array}$ & $\begin{array}{l}\text { Entrepreneurs } \\
\text { obtain training } \\
\text { free }\end{array}$ & $\begin{array}{l}\text { Focus on existing } \\
\text { entrepreneurs - } \\
\text { includes all groups }\end{array}$ & $\begin{array}{l}\text { Coaches monitor the } \\
\text { progress once a week } \\
\text { and have employees }\end{array}$ & $\begin{array}{l}\text { Does not consider } \\
\text { gender directly } \\
\text { but equality in } \\
\text { terms of gender is } \\
\text { achieved. }\end{array}$ & $\begin{array}{l}\text { Although training } \\
\text { is supply-driven } \\
\text { the coaching } \\
\text { approach tends to } \\
\text { assist in a demand } \\
\text { driven culture }\end{array}$ & $\begin{array}{l}\text { The coaching approach } \\
\text { helps entrepreneurs to } \\
\text { identify the markets }\end{array}$ \\
\hline $\begin{array}{l}\text { Premier's } \\
\text { Project }\end{array}$ & $\begin{array}{l}\text { Project run } \\
\text { within } \\
\text { government } \\
\text { structures }\end{array}$ & $\begin{array}{l}\text { Free training and } \\
\text { service }\end{array}$ & $\begin{array}{l}\text { Project cater for new } \\
\text { and existing as well as } \\
\text { all demographic groups }\end{array}$ & $\begin{array}{l}\text { Rationale within the } \\
\text { Free State Growth } \\
\text { and Development } \\
\text { Strategy's attempt to } \\
\text { address poverty }\end{array}$ & $\begin{array}{l}\text { Not specifically } \\
\text { for females but } \\
\text { not ignoring this } \\
\text { reality }\end{array}$ & $\begin{array}{l}\text { In the project } \\
\text { proposal there was } \\
\text { a mix of supply } \\
\text { and demand driven } \\
\text { approach. }\end{array}$ & Some emphasis on markets \\
\hline FDC & $\begin{array}{l}\text { Outsourced } \\
\text { services }\end{array}$ & Paid from the loan & $\begin{array}{l}\text { The inclusion of women } \\
\text { and youth is emphaised } \\
\text { Also emphasis on new } \\
\text { enterprises. }\end{array}$ & $\begin{array}{l}\text { Addressing poverty is } \\
\text { central to the rational } \\
\text { for business support } \\
\text { services }\end{array}$ & $\begin{array}{l}\text { Included women, } \\
\text { even though still } \\
\text { few }\end{array}$ & $\begin{array}{l}\text { Mainly supply-side } \\
\text { driven }\end{array}$ & $\begin{array}{l}\text { Some focus on markets but } \\
\text { in general not enough } \\
\text { attention }\end{array}$ \\
\hline
\end{tabular}




\section{MAIN FINDINGS AND THE CONCLUSION}

In terms of the sustainability of the programmes, three of the business support initiatives were delivered through outsourced state agencies (Seda, the UYF, the FDC), one through an outsourced private public partnership (BESD), and one with direct government involvement. From the comparison it seems as if the government-driven initiative struggles the most to become operational. Different models of funding business support programmes were also presented. In the case of Seda and the UYF, direct business support services were subsidised through a voucher system with a small contribution from the entrepreneur. In the case of the FDC, the cost of business support services was recovered through the loan to the client. In the case the BESD and Premier's project, services were provided at no cost to the entrepreneurs.

In respect of clients, the focus in general has been on previously disadvantaged groups with vulnerable groups such as the youth and females generally mentioned as groups on which the emphasis fell. At the same time the main rationale for business support services was related to addressing poverty. However, very little evidence of successful business support programmes to these groups was recorded. Although a mix of supply-driven and demand-driven approaches characterised the initiatives, the BESD programme probably represents the best example of a more demand-driven approach - despite the fact that it was inherently a training programme. Moreover, the five business support programmes did focus on markets to some degree but seldom made (see Table 1.1).

\section{RECOMMENDATIONS}

There is a need to learn more directly from the international paradigms and practice in order to review the SMME policy and make it focus mainly on a more demand-driven approach

Though it is recommended that SMME policy should focus on a more demand-driven approach, considering the background of this country (South Africa), it is not surprising that business support has been supplydriven. For example, according to the findings in Chapter Five, the majority of entrepreneurs in the Free State have no managerial skills and other business related skills; as a result, it is not easy for business support programmes to be demand-driven (open markets for SMMEs) before providing business related training and assisting in developing business plans. However, the time has of being supply-driven has past; instead, business support programmes should now try to be more demand-driven. This could only be achieved if the SMME policy could focus its attention (in opening markets for SMMEs) to become more demand-driven.

\section{Private sector providers should provide effective services to SMMEs}

This study suggests that the services provided by the private sector have not always been effective. For example, the training and mentorship programme to SMMEs' are of poor quality. If the government could provide rules or guidelines as to what is expected of the private sector in terms of training and mentoring SMMEs, or any other programme that could help support and develop SMMEs, this could improve the services that the private sector provide to SMMEs.

There should be monitoring and evaluation systems available to document the quality of the service delivery to SMMEs in order to ensure compliance with the international standards

Business support programmes should at least record all the training, mentoring and coaching that they provide to SMMEs. Business support programmes should also record the successes and failures of the SMMEs in the Free Sate, and the reasons why the SMMEs are succeeding or failing. Some of the reasons why enterprises fail - as indicated in Chapter Five - is that entrepreneurs lack managerial skills and business skills. Some of them do not know how to write a business plan. Business support programmes should provide training to entrepreneurs before assisting them financially (in the case of those who do not possess the skills). Business support programmes should then mentor and coach entrepreneurs for a period of at least two years after assisting them financially. This will reduce the failure rate and increase the sustainability of enterprises. Moreover, at the end of every financial year, the business support programme should then write a report and submit to the government. The report should include the following:

- $\quad$ It should provide feedback on how business support programmes mentored, coached and trained SMMEs. The reason is consequently in training and mentoring quality. 
- It should include a number of enterprises that had a turnover higher than the previous year.

- It should included enterprises that made a turnover of less than the previous year and provide the reason(s) for the failure. In this regard, the business support programmes should indicate the weakness of the business and try to fill that gap in the next year.

This report could help to formulate a long-term system of monitoring and evaluation of SMMEs and help to increase the sustainability of SMMEs.

The findings of the study clearly indicate that more still needs to be done in the Free State in respect of business support services to SMMEs. Even though recommendations have been made in this study, the dilemma is that there is a need for development of the SMME policy to encourage the empowerment of the entrepreneurs and the development of the SMMEs in the Free State. As far as the literature is concerned, business support programmes have not been adhering to the SMME policy on empowering SMMEs in the Free State.

\section{AUTHOR INFORMATION}

M.S. Mathibe obtained her B.Com. Human Resource Management (2006), B.Com. Honours Marketing (2006), and M.Com Business Management (2010) degrees at the University of the Free State. The topic of my master's thesis was: "Evaluation of business support services to SMMEs in the Free State". I specialise in Marketing, business management and Entrepreneurship, primarily on undergraduate level. My areas of expertise is business management and Marketing. E-mail: Mathibems@ufs.ac.za (corresponding Author)

JH van Zyl. I obtained my B.Com. Marketing (cum laude 1980), B.Com. Marketing Honours (1981), M.Com (1984) and D.Com (1988) degrees at the University of the Free State. The topic of my doctoral thesis was: "The role of marketing productivity and the effect of it on manufacturing firms in South Africa". I specialise in Marketing and Entrepreneurship, primarily on postgraduate and MBA level. My areas of expertise is the drawing up of business plans, marketing plans, strategic environmental plans, tourism sector plans, service delivery plans and turn-around strategy plans. I also focus on entrepreneurial development and community service. I am involved in running entrepreneurial mentorship programs in underprivileged areas, entrepreneurial training with current and new entrepreneurs in the Unit for Entrepreneurship and am busy developing a Social Return on Investment model using the Entrepreneurial development programmes at the Unit for Entrepreneurship. E-mail: vanZylJH@ufs.ac.za

\section{REFERENCES}

1. Adams, M. (2003) Networking and support. In: G. Nieman, J. Hough \& C. Nieuwenhuizen. (Eds) Entrepreneurship: a South African perspective. Pretoria: Van Schaik.

2. Agusupi, P. (2007) Small business development and poverty alleviation in Alexandra, South Africa. Paper prepared for the second meeting of the Society for the Study of Economic Inequality (ECINEQ Society, Berlin; July 12-14 2007) School of Development Studies, University of East Anglia, Norwich, UK.

3. Berry A., Von Blottnitz, M., Cassim, R., Kesper, A., Rajaratnam, B. \& Van Seventer, D.E. (2002) The economics of SMMEs in South Africa. Johannesburg: Trade and Industrial Policy Strategies.

4. Bloch, R. \& Kesper, A. (2000) Supporting the small and medium manufacturing sector in the Highveld production region,. Unpublished report for the Council of Scientific and Industrial Research., Pretoria.

5. CDE (2004) Key to growth: supporting SA's emerging entrepreneurs. Research Report no. 12. CDE. June 2004.

6. Committee of Donor Agencies for Small Enterprise Development (2001) Business development services for small enterprise development: guiding principles for donor intervention, Unpublished paper by the Committee of Donor Agencies, Available at www.sedonors.org. Accessed July 132010.

7. Department of Trade and Industry (DTI) (2002) A guide to the Microeconomic Reform Strategy. a discussion paper 2002, Pretoria: DTI South Africa.

8. Department of Trade and Industry (DTI). (2003) The Integrated Small Business Development Strategy in South Africa 2004 - 2014, Unlocking potential in an enterprising nation. Pretoria: DTI South Africa.

9. Department of Trade and Industry (DTI). (2004) Annual Review of Small Business in South Africa - 2003. Pretoria: Enterprise Development Unit, DTI. 
10. Department of Trade and Industry (DTI). (2005) Overview of the DTI. Online. Available at: http://www.dti.gov.za Accessed July 132010.

11. Department of Trade and Industry (DTI) (2007) Overview of the DTI. Online. Available at: http://www.dti.gov.za Accessed July 132010.

12. Department of the Premier (2006) SMMEs baseline study: Summary Report and Operational Guidelines. University of the Free State: Centre for Development Support.

13. Harper, M. (2005) Introduction. In: M. Harper \&J. Tanburn (Eds) (2005) Mapping the shift in business development services: making markets work for the poor. New Delhi: Nepal ITDG Publishing.

14. Manning, C. (1996) Market access for small and medium-sized producers in South Africa: the case of the furniture industry: Brighton: University of Sussex (Unpublished PhD thesis -).

15. Mathibe, M.S. (2010) An evaluation of business support services to SMMEs in the Free State. Bloemfontein: University of the Free State (Unpublished Master's dissertation).

16. McMillan, J.H. \& Schumacher, S. (2001) Research in education: a conceptual introduction. In: A.C Wilkinson. (2008) Introduction to qualitative research. University of the Free State: Centre for Higher Education Studies and Development.

17. Mcquaid, R. (2002) Entrepreneurship and ICT industries: support from regional and local policies. Regional Studies, Vol. 36(8), pp 909-919.

18. Mkhize, Z. (2006) The entrepreneurship seminar. Royal agricultural society hall in Pietermaritzburg. 08 August 2006.

19. Orford, J. (2005) The role of provincial governments in supporting small enterprise development. Working Paper, Johannesburg: TIPS.

20. Phillips, D.A. (2002) The market-based approach to enterprise assistance: an evaluation of the World Bank's market development grant funds. Mapping the shift in business development services: making markets work for the poor, Warwickshire: ITDG Pub.

21. Pretorius, M., Millard, S.M. \& Kruger, M.E. (2006) Creativity, innovation and implementation: management experience, venture size, life cycle stage, race and gender as moderators, South African Journal of Business Management, Vol. 36(4), pp 55- 68.

22. Republic of South Africa (1995) National Strategy for the Development and Promotion of Small Business in South Africa. Cape Town: DTI.

23. Republic of South Africa (1996) National Small Business Act. Pretoria: Government Printer.

24. Rogerson, C.M. (2001) Redressing urban poverty in post-apartheid South Africa. In F. Wilson, N.Kanji \& E. Braathen (Eds), Poverty reduction: what Role for the state in today's globalized economy. London: Zed.

25. Rogerson, C.M. (2004) The impact of the South African government's SMME programmes: a ten year review (1994-2003), Development Southern Africa, Vol. 21(5), pp 765-784.

26. Rogerson,C.M. (2005) Tourism SMMEs in South Africa: a case for separate policy development, Working Paper 2 of 2005. University of Witwatersrand: TIPS.

27. Rogerson, C.M. (2006) Pro-poor local economic development in South Africa: the role of pro-poor tourism local environment, Vol. 11(1), pp 37-60.

28. Rogerson, C.M. (2007) Supporting small firm development in tourism: South Africa's Tourism Enterprise Programme, The International Journal of Entrepreneurship and Innovation, Vol. 8(9), pp 6-14.

29. Sida (2003) Making markets work for the poor: framework for Sida's support to private sector development. Sweden: Sida.

30. Small Enterprise Development Agency Business Plan (2008) Small Enterprise Development Agency Business Plan 2007/2008.

31. Thurlow, J. \& Wobst, P. (2004) The road to pro-poor growth in Zambia: past lessons and future challenges. Washington DC: International Food Policy Research Institute.

32. von Broembsen, M. (2003) Poverty alleviation: beyond the National Small Business Strategy. Available from: http://www.idasa.org.za/, IDASA budget informational services, Occasional papers. Accessed July 132010

33. World Bank, (2001) Local Economic Development: Quick Reference. Washington DC: The World Bank, Urban Development Division

34. Wren, C. \& Storey, D.J. (2002) Evaluating the effect of soft business support upon small firm performance, Oxford Economic Papers, Vol. 54(2), pp 334-365. 